\title{
Effects of polynyas on the hatching season, early growth and survival of polar cod Boreogadus saida in the Laptev Sea
}

\author{
Caroline Bouchard*, Louis Fortier
}

Québec-Océan, Département de Biologie, Université Laval, Québec, Québec G1V 0A6, Canada

\begin{abstract}
Based on the analysis of otolith microstructure, polar cod larvae and pelagic juveniles (20 to $55 \mathrm{~mm}$ standard length) sampled in September in the Laptev Sea (Siberian Arctic Ocean) hatched under sea-ice cover from mid-March to early July in 2003, and from early January to early July in 2005. During the polar night in January and February 2005, frequent winter polynyas (mesoscale areas of open water amidst ice cover) likely provided the first-feeding larvae with the minimum light necessary to detect and capture plankton prey. The absence of survivors from January to mid-March 2003 coincided with a low occurrence of polynyas. On average, polar cod 59 to $171 \mathrm{~d}$ old were $4 \mathrm{~mm}$ longer at a given age in 2005 than in 2003, a difference arising early in larval life and reflecting faster growth and more frequent winter-spring polynyas in 2005. Earlier hatching and faster growth resulted in young-of-the-year polar cod on average $8.6 \mathrm{~mm}$ longer in September $2005(34.8 \mathrm{~mm})$ than in September $2003(26.2 \mathrm{~mm})$. Assuming that a larger pre-winter size provides protection against predation, the increasing frequency of winter-spring polynyas on the immense Siberian shelves could improve early survival and population size in polar cod.
\end{abstract}

KEY WORDS: Polar cod - Boreogadus saida - Hatching season - Growth - Survival · Polynyas · Laptev Sea $\cdot$ Arctic Ocean $\cdot$ Climate

Resale or republication not permitted without written consent of the publisher

\section{INTRODUCTION}

The sea-ice cover of the Arctic Ocean is shrinking rapidly in response to global warming. Reductions in sea ice cover have been most spectacular in summer, but significant losses of winter ice, increasing sharply since 2005, have also been observed (see Stroeve et al. 2007 for a recent review). Losses of winter sea ice have occurred primarily in the Siberian Arctic where seasonal ice has replaced multi-year ice (Nghiem et al. 2006). In the Laptev Sea, satellite observations indicate a trend towards earlier melt onset and more frequent winter polynyas (Bareiss \& Gorgen 2005). The central role of polynyas in sustaining primary production and the pelagic food web of the Arctic Ocean is becoming increasingly apparent (e.g. Deming et al. 2002 and references therein). In particular, relatively high phytoplankton biomass and temperatures in polynyas pro- mote the feeding and growth of key elements of this web, including large calanoid copepods and the early stages of polar cod (Michaud et al. 1996, Ringuette et al. 2002, Fortier et al. 2006).

Polar cod spawn under the ice in winter and the buoyant eggs rise to the ice-water interface (Graham \& Hop 1995, Ponomarenko 2000). Incubation time is presumed to range from 45 to $90 \mathrm{~d}$ at the sub-zero temperatures prevailing in ice-covered arctic waters (Rass 1968). Hence, winter spawning is seen as an adaptation to match the hatching and first feeding of polar cod larvae with early-summer production of copepod eggs and nauplii, their main prey (e.g. Graham \& Hop 1995, Fortier et al. 1995). Consistent with this hypothesis, hatching occurs from mid-May to mid-July in the Northeast Water polynya (Greenland Sea), coinciding with the opening of the polynya and the short season of intense biological production (Fortier et al. 2006). By 
contrast, in the Barents and Kara Seas, newly-hatched larvae occur over a protracted period from March to September (Baranenkova et al. 1966 and references therein), suggesting that larvae hatching in winter well before the early-summer bloom can, nevertheless, survive.

In the present study we used otolith analysis to backcalculate the hatch dates and early growth trajectories of young polar cod sampled in the Laptev Sea in September 2003 and 2005. To elucidate the potential response of this key species to a future lighter ice regime, we related interannual differences in hatch dates and early survival to sea-ice conditions and the frequency of polynyas in winter and spring.

\section{MATERIALS AND METHODS}

Study area. The extensive and shallow (50 $\mathrm{m}$ on average) continental shelf of the Laptev Sea is separated by a steep slope from the deep Nansen Basin (Fig. 1). Waters from the Kara Sea and Nansen Basin enter the Laptev Sea from the west. The main outflow is to the East Siberian Sea and the Arctic Basin. Surface circulation is counter-clockwise in the shallow coastal area. Because of the immense runoff from the Lena River and secondary rivers, the eastern sector is warmer and less saline than the western sector where Arctic Basin waters prevail (Timokhov 1994).

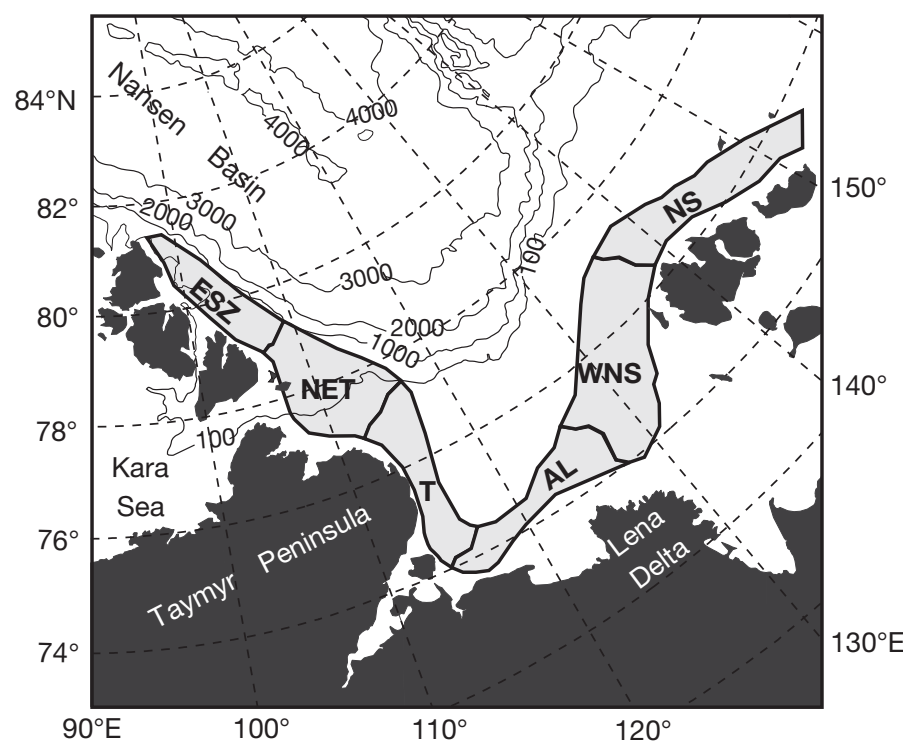

Fig. 1. Bathymetric map (isobaths in $\mathrm{m}$ ) of the Laptev Sea in the Siberian Arctic Ocean showing the distribution of the main polynyas described by Zakharov (1997): Eastern Severnaya Zemlya (ESZ); Northeastern Taymyr (NET); Taymyr (T); Anabar Lena (AL); Western New Siberian (WNS) and New Siberian (NS)
Typically, the Laptev Sea is almost entirely covered with ice from October to June. The southern and central parts of the shelf often become ice-free during summer, while the western shelf and the deep region remain covered with multi-year ice. In winter and spring, a vast system of flaw polynyas reaching up to $2000 \mathrm{~km}$ in length and $250 \mathrm{~km}$ in width (Zakharov 1997) forms when offshore winds (or flaws) entrain the mobile pack ice away from the landfast ice (Fig. 1).

Percentage ice concentration. Daily, cloud-independent sea ice concentrations for the study area in 2003 and 2005 were extracted from the National Snow and Ice Data Center (NSIDC) Special Sensor Microwave Imager (SSM/I) archives using the Nasateam algorithm (Cavalieri et al. 1990). Daily ice concentrations in each $25 \times 25 \mathrm{~km}$ pixel of the Laptev Sea were processed into weekly averages. The weekly values were then averaged for the general marine region between $72.658^{\circ}$ and $82.177^{\circ} \mathrm{N}$ and $91.194^{\circ}$ and $139.167^{\circ} \mathrm{E}$, as well as for the pixels corresponding to each of the 6 polynyas described by Zakharov (1997).

Sampling. Polar cod larvae and juveniles were collected from 1 to 11 September 2003 and 10 to 21 September 2005 during the Nansen and Amundsen Basins Observational System (NABOS) annual expeditions of the icebreaker Kapitan Dranitsyn to the Laptev Sea. Ice conditions permitting (i.e. at 15 of 26 stations in 2003 and 30 of 41 stations in 2005), a sampler consisting of 2 zooplankton nets (500 and $750 \mu \mathrm{m}$ mesh, $1 \mathrm{~m}^{2}$ mouth aperture, TSK $^{\circledR}$ flowmeter) mounted side by side on a metal frame was towed obliquely to a depth of $47 \pm 8 \mathrm{~m}$ (mean \pm SD) in 2003 and $71 \pm 11 \mathrm{~m}$ in 2005 . The average ship speed was 2 knots and the angle of the cable relative to the horizon was maintained at $60^{\circ}$. Deployment depth was estimated from the angle of the wire and the length of cable paid out. On average, the tows lasted $15 \pm$ 3 min (mean \pm SD) in 2003 and $19 \pm 4$ min in 2005. In 2004, very heavy ice conditions in the Laptev Sea in September prevented any horizontal net deployment and, consequently, no young polar cod were sampled in that year. All fish were sorted from the zooplankton samples and measured fresh under a dissecting microscope and/or photographed fresh with a digital camera using mm-gridded paper as background for later measurement with an image analysis system. Specimens were then preserved individually in $20 \mathrm{ml}$ vials filled with $95 \%$ ethanol.

Length and age determination. In 2003, 49 young polar cod out of the 170 sampled were measured and photographed against mm-gridded paper (fresh standard length, FSL, to the nearest $0.5 \mathrm{~mm}$ ) prior to individual preservation in ethanol. The remaining $121 \mathrm{fish}$ were preserved directly in ethanol without being 
photographed fresh. In the laboratory, the 170 preserved fish were photographed against the gridded background and the preserved standard length of each fish was estimated from the photographs using SigmaScanPro ${ }^{\oplus}$. The linear regression of fresh standard length on preserved standard length for the 49 polar cod measured fresh at sea (FSL $=1.022$ preserved SL + $1.593, \mathrm{r}^{2}=0.976, \mathrm{n}=49$, for SL ranging from 17 to $56 \mathrm{~mm}$ ) was used to estimate the fresh standard lengths of the remaining 121 fish. In 2005, all 427 fish were photographed at sea before preservation and fresh standard length was estimated from the photographs.

Our team has confirmed that increments are formed daily in larval polar cod by using tetracycline and alizarine to mark the otoliths of larvae collected in the North Water Polynya (northern Baffin Bay) and reared at the near-zero temperatures prevailing at capture ( $\mathrm{L}$. Fortier, C. Boucher \& P. Sirois unpubl. data). In the present study, the left and right lapilli of all 170 fish sampled in 2003, and 196 (46\%) of the fish sampled in 2005 were dissected and mounted in Crystal Bond ${ }^{\circledR}$ thermoplastic glue on glass slides. For each fish, one lapillus was analyzed at $1000 \times$ magnification using a microscope linked to an image analysis system (Image Pro Plus ${ }^{\circledR}$ software). The radius of the core and the width of each subsequent increment were measured. A first operator enumerated and measured increments on all 366 otoliths. Six weeks later, the same operator enumerated once more the increments of 75 of these otoliths (selected at random) to verify the reliability of the initial reading. In addition, a second independent operator enumerated increments on 116 otoliths selected at random from the 366 . The initial and second estimates of increment numbers were highly correlated $\left(r^{2}=0.975, n=191\right)$ and the slope of the regression (0.99) did not differ significantly from $1(t=0.970$, $\mathrm{p}=0.333$ ). The initial reading by the first operator was retained as an estimate of age for subsequent analyses.

Age was strongly and linearly correlated to standard length (SL) for the 196 larvae aged by otolith analysis in 2005 (age $\left.=4.868 \mathrm{SL}-10.595, \mathrm{r}^{2}=0.89, \mathrm{p}<0.0001\right)$, enabling us to use age-length keys to estimate the ages of the remaining 231 fish from their SL. Young fish in a given $1 \mathrm{~mm}$ length class were randomly assigned an age according to the known age probability function for that $1 \mathrm{~mm}$ length class.

The hatch date of each individual fish was obtained by subtracting age from date of capture. The hatch date frequency distributions (HFD) for 2003 and 2005 were built by grouping polar cod hatched within the same week, starting on 1 January.

SL was linearly correlated to otolith radius (OR) in $2003\left(\mathrm{SL}=0.354+0.207 \mathrm{OR}, \mathrm{r}^{2}=0.861, \mathrm{n}=170\right)$ and $2005\left(\mathrm{SL}=1.905+0.196 \mathrm{OR}, \mathrm{r}^{2}=0.923, \mathrm{n}=196\right)$, con- firming that otolith growth is a reliable estimator of somatic growth, and enabling us to back-calculate the length at age of individual fish from increment width using the biological intercept method (Campana \& Jones 1992) and a hatch length of $6.5 \mathrm{~mm}$. Back-calculated lengths at age were compared between years by repeated-measures MANOVA to take into account the auto-correlation generated by back-calculating size at age using the same individuals at different ages.

\section{RESULTS}

\section{Winter/spring ice regime in the Laptev Sea in 2003 and 2005}

The Laptev Sea polynyas opened earlier and more frequently in the winter of 2005 than in the winter of 2003 (Fig. 2). While the study area was completely covered with ice in January and February 2003, sea-ice concentrations were as low as $50 \%$ in the Eastern Severnaya Zemlya (ESZ) and Northeastern Taymyr (NET) polynyas in January and February 2005 (Fig. 2a-d). In 2003, the first significant opening of the ESZ, NET, Taymyr ( $\mathrm{T}$ ) and Anabar Lena (AL) polynyas was delayed until mid-March (Fig. 2e). Little polynya activity was seen in April 2003 (Fig. 2g). By contrast, the Western New Siberian (WNS) and New Siberian (NS) polynyas were opened in April 2005 (Fig. 2h). By midMay of both years, the polynyas started to open rapidly (Fig. 2i,j) and, by June, large areas of the coastal Laptev Sea were ice free (Fig. 2k,l). An animation contrasting the weekly evolution of the ice cover in the 2 years is available at www.arcticnet-ulaval.ca./ppt/ ice_animation_laptev.pps.

As a result of interannual differences in polynya activity, the area of ice-free water from late January to late February was from 3 to 5 times larger in 2005 than in 2003 (Fig. 3). By the second week of March, the situation had reversed with more open water in 2003 than in 2005. By late April of both years, the surface of open water began to increase exponentially (Fig. 3).

\section{Distribution of young polar cod in the Laptev Sea in September 2003 and 2005}

In 2003, ice-cover conditions allowed us to sample the ichthyoplankton at 15 stations in the eastern sector of the Laptev Sea (Fig. 4). Out of 170 polar cod larvae/juveniles, 169 were collected at 2 stations on the upper continental slope of the central Laptev Sea at station depths of approximately 100 and $200 \mathrm{~m}$. One large $(55.6 \mathrm{~mm} \mathrm{SL})$ juvenile was collected over the deep (>3000 m) basin (Fig. 4). Excluding the latter 

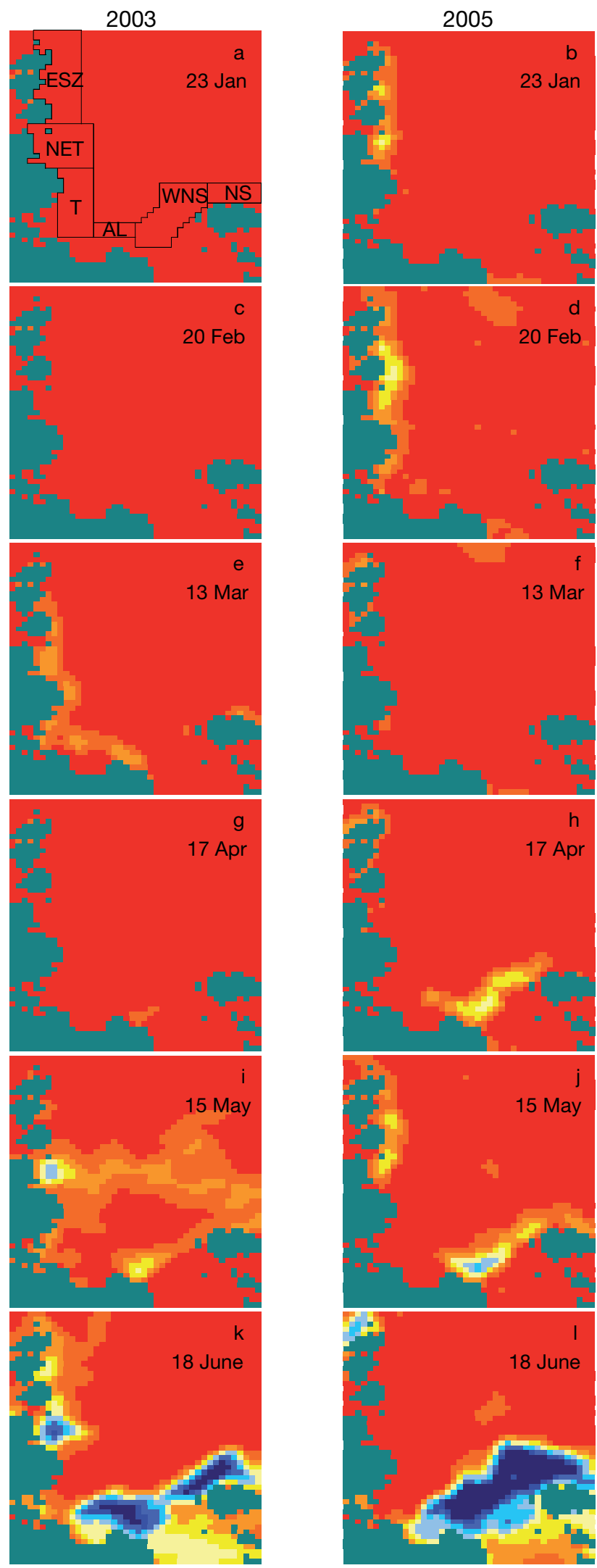

Ice concentration (\%)

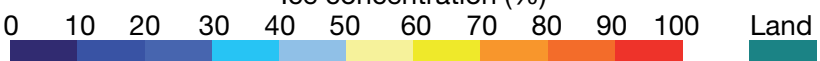

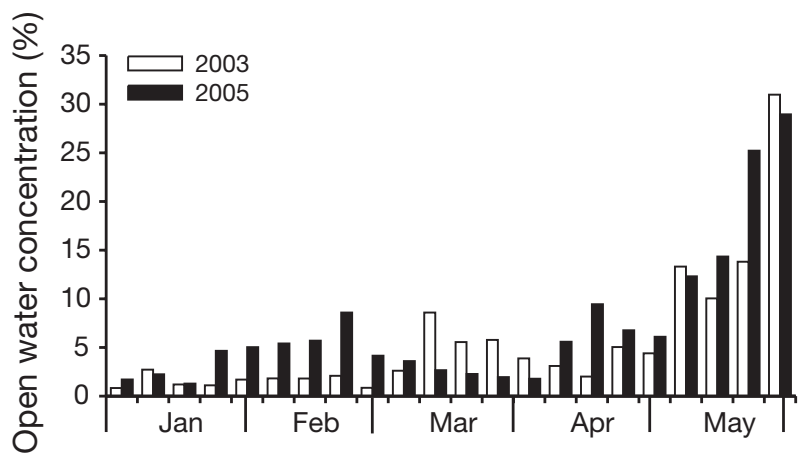

Fig. 3. Cumulative open water fraction in the area of the main polynyas described by Zakharov (1997) by week from January to May in 2003 and 2005

specimen, the SL of polar cod sampled in 2003 ranged from 16.7 to $41.8 \mathrm{~mm}$ (mean $\pm \mathrm{SD}$ : $26.2 \pm 5.2 \mathrm{~mm}$ ) (Fig. 5). No polar cod were caught at the other 12 stations where ice concentrations ranged from 20 to $80 \%$ and depth from 100 to $>3000 \mathrm{~m}$.

In 2005 , a total of 427 young polar cod was collected at 24 of the 30 stations where ice conditions allowed us to sample (Fig. 4). Only one fish was collected at the 7 stations west of $120^{\circ} \mathrm{W}$. The highest concentrations of fish were found along the $1000 \mathrm{~m}$ isobath. SL ranged from 14.4 to $59.9 \mathrm{~mm}$ (mean $\pm \mathrm{SD}$ : $36.6 \pm 7.6 \mathrm{~mm}$ ) in 2005 (Fig. 5). Average age and length at a station were linearly correlated to salinity in the surface (0 to $30 \mathrm{~m})$ layer $\left(\right.$ age $=10.09 \mathrm{~S}-132.7, \mathrm{r}^{2}=0.392, \mathrm{p}=0.0014 ; \mathrm{SL}=$ $2.28 \mathrm{~S}-31.9, \mathrm{r}^{2}=0.423, \mathrm{p}=0.0007$ ), with small larvae being associated with low salinity.

\section{The hatching season of polar cod in 2003 and 2005}

Except for the single large specimen (sampled over the deep basin) hatched in the second week of January, 169 of the 170 fish collected in 2003 were hatched over the 3.5 mo period between mid-March and early July (Fig. 6). Hatching frequency was highest in May in 2003. Polar cod collected in 2005 hatched continually over a 6 mo period from the first week of January to the first week of July, with one larva hatching in the 3rd week of July (Fig. 6). Hatching was most frequent

Fig. 2. Sea-ice concentrations in the Laptev Sea (weekly averages) for selected weeks in the winter-spring of 2003 and 2005. The main polynyas described by Zakharov (1997) are indicated in (a), viz. Eastern Severnaya Zemlya (ESZ), Northeastern Taymyr (NET), Taymyr (T), Anabar Lena (AL), Western New Siberian (WNS) and New Siberian (NS). The complete series of weekly averages is available at www. arcticnet-ulaval.ca./ppt/ice_animation_laptev.pps 


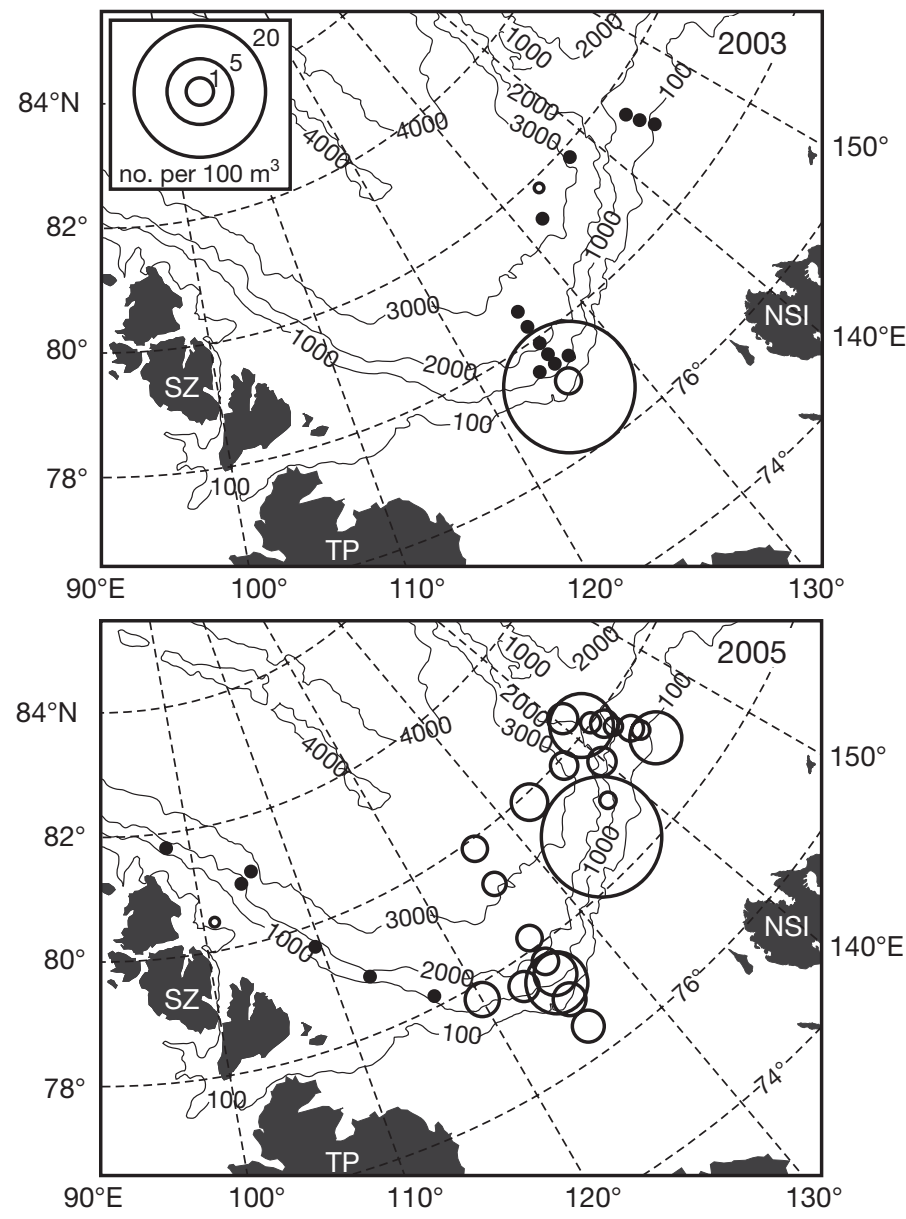

Fig. 4. Boreogadus saida. Abundance (no. $100 \mathrm{~m}^{-3}$ ) of polar cod larvae and juveniles at the stations sampled in September 2003 and 2005 in the Laptev Sea. - indicates zero values. SZ: Severnaya Zemlya; TP: Taymyr Peninsula; NSI: New Siberian Islands. Isobaths in metres

in April and May. In both years, hatching was completed before the overall ice cover of the Laptev Sea declined to $<50 \%$.

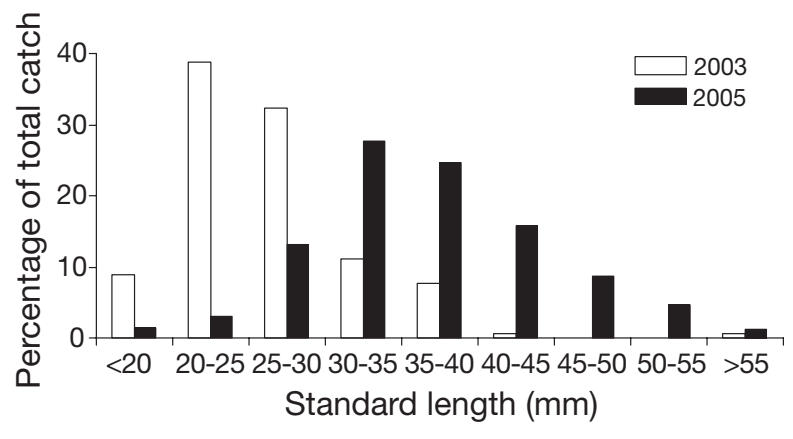

Fig. 5. Boreogadus saida. Length frequency distributions of polar cod larvae and juveniles collected in the Laptev Sea in September $2003(n=170)$ and September $2005(n=427)$

$3.98 \mathrm{~mm}$ longer in 2005 than in 2003. The average hatch mark radius, an index of hatching size, was not significantly different between the 2 years (unequal variance $t$-test, $F=0.671, \mathrm{p}=0.41$ ), implying that interannual differences in length at age were not related to differences in hatching length. The intercept in $2003(1.899 \mathrm{~mm})$ was unrealistically small compared to the known hatching size of polar cod (i.e. 3.5 to $6.5 \mathrm{~mm}$, Baranenkova et al. 1966). This discrepancy and the lack of difference in hatching sizes meant that the deficit in length at age in 2003 developed after hatching, sometime during the first $60 \mathrm{~d}$ of life.

Estimates of early growth based on otolith increment width confirmed that larval growth in the first 2 mo of life was invariably higher in 2005 than in 2003 (repeated measures MANOVA, Wilk's lambda, $\mathrm{p}<0.0001 ; \mathrm{n}=365$, Fig. 8). Average otolith growth was particularly low during the first $20 \mathrm{~d}$ of life in 2003, consistent with the notion that the deficit in length at age observed in 2003 relative to 2005 for fish 59 to $171 \mathrm{~d}$ old (Fig. 7) arose soon after hatching.

\section{Interannual differences in the average growth of young polar cod}

The slopes of the regression of standard length on age for fish 59 to $171 \mathrm{~d}$ old (the age range over which data were available in both years) did not differ significantly between 2003 and 2005 (ANCOVA, $\mathrm{p}=0.158$, Fig. 7). A significant difference $(p<0.0001)$ in the intercepts $(1.899 \mathrm{~mm}$ in 2003 versus $5.881 \mathrm{~mm}$ in 2005) indicated that, at a given age, fish were on average

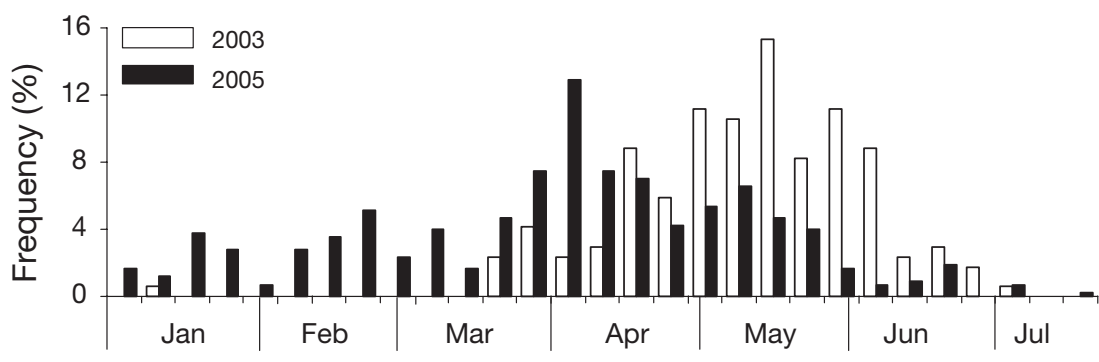

Hatch date

Fig. 6. Boreogadus saida. Hatch date frequency distributions of polar cod collected in the Laptev Sea in September 2003 ( $\mathrm{n}=170)$ and September 2005 (n = 427). Fish hatched in the same $7 \mathrm{~d}$ calendar interval were grouped into a sub-cohort represented by a single bar 


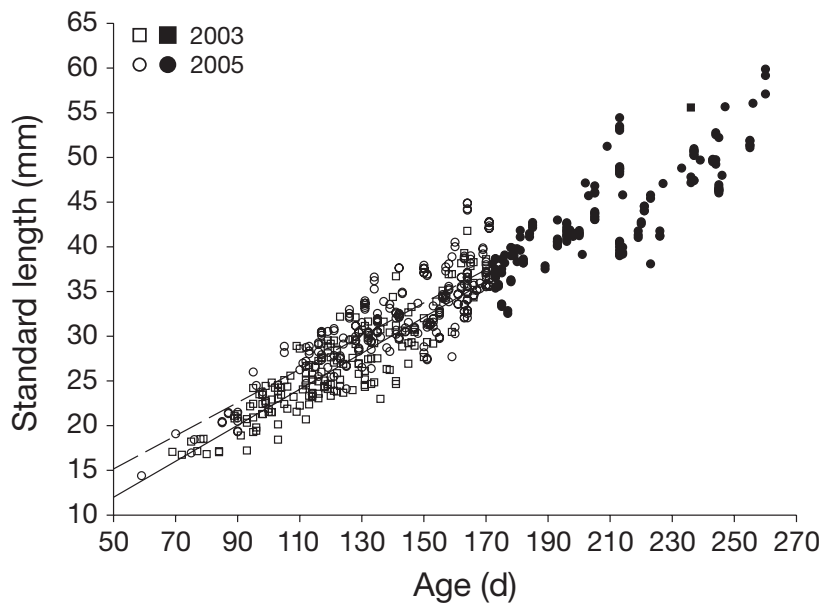

Fig. 7. Boreogadus saida. Regressions of standard length (SL) on age for polar cod larvae and juveniles of age $\leq 171 \mathrm{~d}$ sampled in the Laptev Sea in September 2003 (ㅁ) and September 2005 (O); filled symbols are data not included in the regression (age $>171 \mathrm{~d}$ ). Regression for 2003: $\mathrm{SL}=1.899+0.202$ age, $\mathrm{r}^{2}=0.784, \mathrm{n}=169(-)$; regression for 2005: $\mathrm{SL}=5.881+$ 0.186 age, $r^{2}=0.706, n=260(---)$

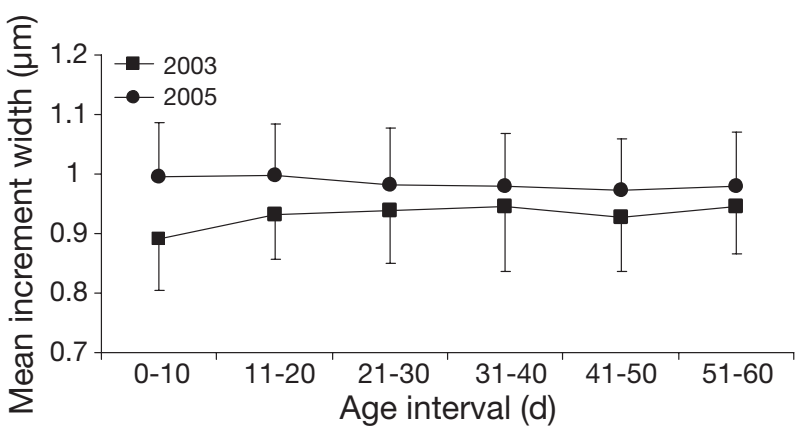

Fig. 8. Boreogadus saida. Mean increment width for $10 \mathrm{~d}$ intervals of age from 0 to $60 \mathrm{~d}$ determined by the analysis of the otoliths of young polar cod collected in the Laptev Sea in September 2003 ( $\mathrm{n}=170)$ and September 2005 ( $\mathrm{n}=195)$. Vertical range bars represent SD

\section{Early growth in relation to hatch date and year}

Average lengths at ages 10, 30 and $60 \mathrm{~d}$ were reconstructed from the otoliths (Fig. 9). In 2005, average length at age varied relatively little over the long hatching season, with no obvious trend from winter to spring. In 2003, length at age was highest in late March and early April and tended to decline progressively thereafter to reach minimum values in June (note that except for the large specimen captured in January, no growth data were available from January to mid-March 2003 as no surviving larvae hatched in that period were sampled). Early growth was similar between the 2 years during late March and early April (Fig. 9), the only time in winter when the western polynyas opened in 2003 (Fig. 3). Polar cod larvae were significantly longer at age in 2005 than in 2003 from late April to mid-June (Fig. 9), a period corresponding to the wider opening of the southern polynyas in 2005 relative to 2003 (Fig. 3).

\section{DISCUSSION}

\section{The hatching season of polar cod: contrasting different regions of the Arctic Ocean}

In the Barents Sea, newly-hatched polar cod (3.5 to $8 \mathrm{~mm}$ ) occurred primarily in May, June and July (Baranenkova et al. 1966, their Table 2). Similarly, polar cod were hatched from mid-May to late June in the North Water polynya of Baffin Bay (M. Ringuette, Université Laval, pers. comm.) and from mid-May to mid-July in the Northeast Water polynya of the Greenland Sea (Fortier et al. 2006). Based on our own length-age relationships, a much longer 6-mo hatching season (March to August) is suggested for the Kara Sea by the wide range of lengths of fish captured in September (6.5 to $38 \mathrm{~mm}$, Baranenkova et al. 1966, their Fig. 8). In the Beaufort Sea, both the occurrence of newly-hatched larvae and the back-calculation of the hatchdate frequency distribution of surviving juveniles indicate a long hatching period from early February to early July (P. Lafrance, Université Laval, pers. comm.). In the present study, surviving polar cod juveniles collected in September in the Laptev Sea were hatched from early January to early July. In summary, 2 distinct hatching patterns emerge from the available observations. First, a short hatching period from May to June/July centered on the ice break-up and the onset of biological production (Barents Sea, North Water and Northeast Water). Second, a protracted hatching season (January to July/August) with most larvae emerging well before the ice break-up (Kara, Laptev and Beaufort Seas).

Fortier et al. (2006) stressed the importance of maximizing summer growth and pre-winter size for winter survival. Based on this constraint, we see 2 nonexclusive interpretations for the distinct hatching patterns. A first interpretation is that prey availability and summer temperatures dictate the hatching season of polar cod (Fortier et al. 2006). In regions where a relatively long ice-free season prevails (e.g. Barents Sea, North Water, Northeast Water), high prey availability and warm summer temperatures allow the larvae to grow fast and achieve a sufficient pre-winter size despite late hatching. By contrast, in regions where the ice-free season is short (e.g. Kara, Laptev and Beaufort Sea) the larvae must hatch early in winter or spring to achieve the minimum pre-winter size because of slow growth at low temperature and low food availability 


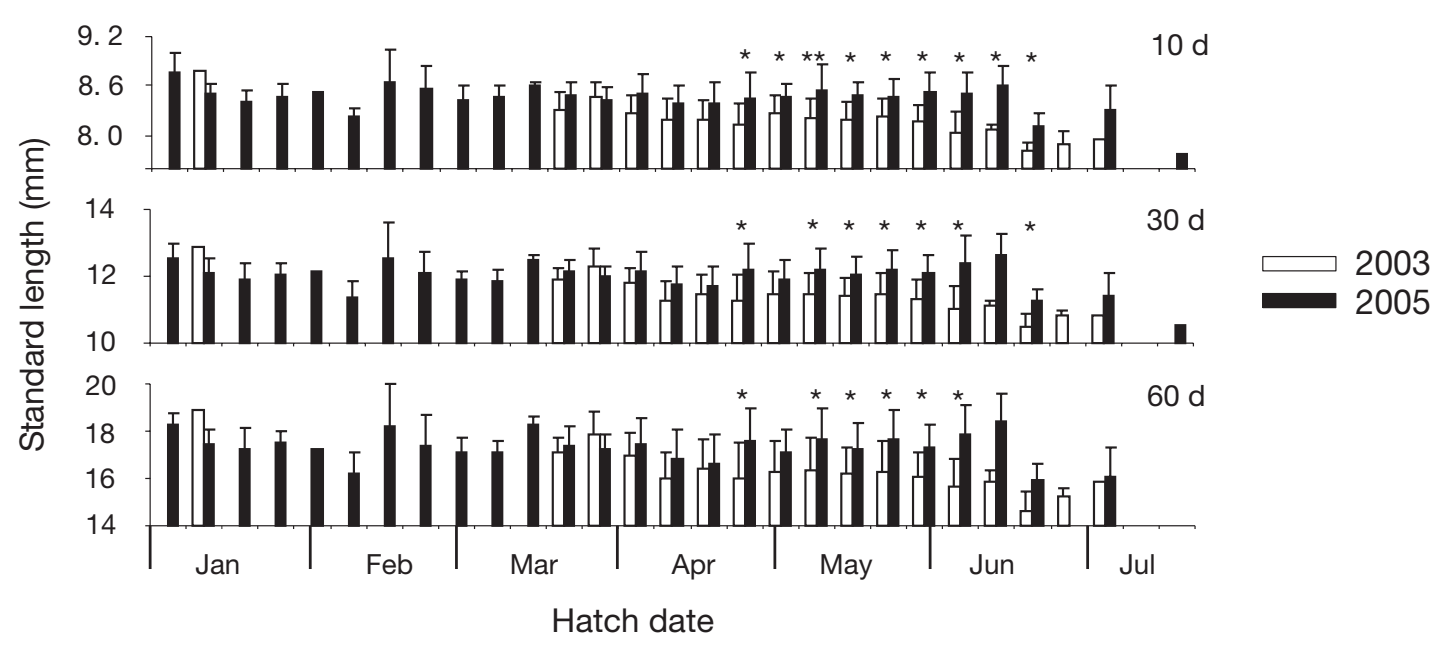

Fig. 9. Boreogadus saida. Back-calculated standard length based on otolith radius at different ages (10, 30 and $60 \mathrm{~d})$ by hatching week for young polar cod collected in the Laptev Sea in September 2003 and September 2005. Data are means + SD. Statistically significant differences between the 2 years are indicated $\left(t\right.$-test): ${ }^{*} \mathrm{p}<0.05 ;{ }^{* *} \mathrm{p}<0.001$

under the ice. In support of this interpretation, polar cod larvae hatched in the Northeast Water grew on average faster $\left(0.225 \mathrm{~mm} \mathrm{~d}^{-1}\right.$, Fortier et al. 2006, their Fig. 3) than larvae hatched in the Laptev Sea (0.186 to $0.202 \mathrm{~mm} \mathrm{~d}^{-1}$ ).

A different interpretation is that winter temperature dictates the hatching season of polar cod by limiting larval survival. The sub-zero temperature prevailing in ice-filled waters slows the swimming activity of Atlantic cod Gadus morhua larvae, which become completely inactive at $-1.8^{\circ} \mathrm{C}$ (Valerio et al. 1992). In the Northeast Water, the feeding of polar cod larvae decreased with decreasing temperature in the range +4 to $-1.8^{\circ} \mathrm{C}$ (Michaud et al. 1996). Despite reduced discharge in winter, large Arctic and sub-arctic rivers typically form extensive plumes of fresh to brackish water under the coastal landfast ice where polar cod larvae develop (e.g. Fortier et al. 1996). Surface temperature vary with salinity from ca. $-1.8^{\circ} \mathrm{C}(\mathrm{S}=33)$ to $0^{\circ} \mathrm{C}(\mathrm{S}=0)$. Temperature differences in this sub-zero range have large impacts on physiological and enzymatic processes. The regression of age on the salinity of the surface layer $(0-30 \mathrm{~m})$ pointed to a salinity of ca. 13.1 at hatch in the Laptev Sea, corresponding to a temperature of $-0.7^{\circ} \mathrm{C}$. These values are consistent with the salinities and temperatures experienced by first-feeding larvae at the base of the freshwater plume of the Great Whale River in Hudson Bay (Ponton \& Fortier 1992). We suggest that, in coastal seas influenced by large rivers such as the Kara (Ob and Ienisseï rivers), Laptev (Lena River) and Beaufort (Mackenzie River) Seas, temperatures above $-1.8^{\circ} \mathrm{C}$ in the brackish surface layer allow polar cod larvae to feed and grow in winter. By contrast, in regions with less (Barents Sea) or no significant freshwater influence (North
Water, Northeast Water), the extremely low temperature $\left(-1.8^{\circ} \mathrm{C}\right)$ prevailing under the ice in winter would prevent the swimming and feeding of early hatchers, and hatching must be delayed until the surface layer warms up in late spring. Under this interpretation, the hatching window that allows the larvae to survive and attain a minimum pre-winter size would extend from January to July in coastal seas influenced by large rivers, and would be limited to the period from May to July elsewhere in the Arctic.

\section{Polynyas and the survival of winter-hatched polar cod larvae}

Fish larvae are visual feeders that need a minimum light intensity to detect and capture their plankton prey (usually the eggs and nauplii of copepods). In southeastern Hudson Bay in spring, under-ice light is almost completely blocked by the snow and ice cover and the turbid plume of the Great Whale River (Ponton \& Fortier 1992, Fortier et al. 1996). The number of copepod nauplii ingested by recently-hatched polar cod larvae (4.3 to $9.8 \mathrm{~mm}$ SL) increased with the product of light intensity by nauplii concentration, indicating that first-feeding success depends on both prey abundance and light (Fortier et al. 1996).

In the present study, the capture in September of juveniles hatched from January to early July clearly shows that polar cod larvae fed, grew and survived in winter. This raises the intriguing question of the light available to first-feeding polar cod hatched under the ice in early winter. From 75 to $82^{\circ} \mathrm{N}$, the polar night prevails until the end of January. The only light available at that time is some diffuse solar light around solar 
noon. Direct sunlight returns by early February, albeit at a very low intensity and from a low angle on the horizon so that most of it is reflected by the snow/ice cover. We propose that open water in winter polynyas provide polar cod larvae hatched in January and February with the light necessary for prey perception and capture. In support of this hypothesis, seasonal and interannual differences in the HFD generally reflected the frequency and extent of winter/spring polynyas. Excluding one outlier (Week 3) from the analysis, hatching frequency in January and February was significantly correlated to the fraction of open water in the Laptev Sea polynyas $\left(\mathrm{r}^{2}=0.632, \mathrm{p}=0.018, \mathrm{n}=8\right.$ weeks $)$.

Also in support of this hypothesis was the correspondence between the near absence of survivors hatched from January to mid-March 2003 (Fig. 6) and the low fraction of open water $(<3 \%)$, with survival starting only in mid-March when the first significant opening of polynyas occurred in the western sector of the Laptev Sea (Fig. 2). Of course, 169 of the 170 polar cod sampled in 2003 came from only 2 relatively shallow stations with 7 and 162 fish, respectively (Table 1). Thus, the HFD of this sample from the upper continental slope may have been unrepre- sentative of the actual HFD of the population in 2003. To evaluate the possibility of a spatial bias, HFDs were calculated after grouping same-depth stations in 2005 to increase sample size (Table 1). There was no obvious trend in HFD with station depth. But several stations (or group of stations with same depth) where few larvae were collected showed little hatching in June and July (Table 1). Therefore, in some instances, an HFD based on a limited number of stations with small sample sizes would not have detected hatching in these months in 2005. However, the low-frequency hatching in June and July 2005 was detected at stations where sample sizes were large (55 to 113 fish, Table 1). This suggests that, despite the limited spatial distribution of positive stations, sample size (170) in 2003 was sufficient to detect low-frequency hatching. Hence, assuming little interannual variability in spawning season (e.g. Cushing 1969), the zero frequencies from January to mid-March in the HFD of polar cod in 2003 (with the exception of the one fish hatched in January) likely resulted from low survival.

Another question raised by the hatching of polar cod larvae in winter is that of the availability of plankton

Table 1. Boreogadus saida. The number of polar cod larvae and juveniles hatched in a given week and grouped by station depth (m) in 2003 and 2005

\begin{tabular}{|c|c|c|c|c|c|c|c|c|c|c|c|c|c|c|c|c|c|c|}
\hline & \multicolumn{3}{|c|}{$-2003-$} & \multirow[b]{2}{*}{67} & \multirow[b]{2}{*}{98} & \multirow[b]{2}{*}{110} & \multirow[b]{2}{*}{218} & \multirow[b]{2}{*}{500} & \multirow[b]{2}{*}{1170} & \multirow[b]{2}{*}{1320} & \multirow{2}{*}{$\begin{array}{c}-2005 \\
1420\end{array}$} & \multirow[b]{2}{*}{1500} & \multirow[b]{2}{*}{1600} & \multirow[b]{2}{*}{1700} & \multirow[b]{2}{*}{1800} & \multirow[b]{2}{*}{2400} & \multirow[b]{2}{*}{2800} & \multirow[b]{2}{*}{3000} \\
\hline & 100 & 200 & 3000 & & & & & & & & & & & & & & & \\
\hline 1 Jan & & & & 1 & 1 & 1 & & & & & 1 & 2 & & & & & & 1 \\
\hline 8 Jan & & & 1 & & & & & & & & & 2 & 1 & 1 & 1 & & & \\
\hline $15 \mathrm{Jan}$ & & & & 1 & & 3 & & & & & 8 & 2 & 1 & & 1 & & & \\
\hline $22 \mathrm{Jan}$ & & & & & 2 & 1 & 1 & & & & 3 & 2 & & 1 & 1 & & 1 & \\
\hline 29 Jan & & & & & & & & & & & & 2 & & & & & & 1 \\
\hline 5 Feb & & & & & 5 & & & & & & 2 & 2 & 1 & & 2 & & & \\
\hline $12 \mathrm{Feb}$ & & & & 1 & & 1 & & & & 1 & & 9 & 1 & & 1 & & & 1 \\
\hline $19 \mathrm{Feb}$ & & & & & 2 & 2 & & & & & 4 & 3 & 2 & 1 & 3 & 1 & 1 & 3 \\
\hline 26 Feb & & & & 1 & 1 & & & & & 1 & 2 & 2 & 1 & & 1 & & & 1 \\
\hline 5 Mar & & & & 1 & 1 & & 1 & & & & 3 & 7 & & 1 & 1 & & & 2 \\
\hline 12 Mar & & & & & 1 & & & & & & & 3 & 1 & & & & 1 & 1 \\
\hline 19 Mar & & 4 & & 1 & 2 & & 1 & 1 & & & & 5 & 4 & 1 & 1 & 2 & & 2 \\
\hline 26 Mar & 1 & 6 & & & & & & 1 & & & 7 & 10 & 5 & & 5 & & 1 & 3 \\
\hline 2 Apr & & 4 & & & 5 & 2 & & 1 & & 3 & 4 & 17 & 10 & & 3 & 2 & & 8 \\
\hline 9 Apr & 1 & 4 & & 1 & 3 & 1 & 1 & 3 & & 1 & 4 & 6 & 6 & & 2 & 1 & 1 & 2 \\
\hline 16 Apr & & 14 & & 1 & 3 & & & 1 & 1 & & 2 & 10 & 7 & & 2 & 1 & 2 & \\
\hline $23 \mathrm{Apr}$ & & 10 & & & 1 & & 1 & 1 & 1 & 1 & & 6 & 2 & & 2 & & 1 & 2 \\
\hline $30 \mathrm{Apr}$ & 1 & 19 & & & 1 & & & & & 2 & 3 & 5 & 7 & & & 1 & & 4 \\
\hline 7 May & 1 & 17 & & & 1 & & & 1 & & 2 & 3 & 5 & 7 & 1 & 2 & & 1 & 5 \\
\hline 14 May & 1 & 25 & & & & & & & 1 & & 3 & 6 & 3 & 2 & 2 & 1 & 1 & 1 \\
\hline 21 May & 1 & 13 & & & & 1 & & & & & 3 & 4 & 4 & & 2 & 1 & 2 & \\
\hline 28 May & & 19 & & 1 & & 1 & & 2 & & & & 1 & & 1 & 1 & & & \\
\hline 4 Jun & & 15 & & & & & & & & & 1 & 1 & 1 & & & & & \\
\hline 11 Jun & 1 & 3 & & & & 1 & & & & & 1 & & 1 & & & & 1 & \\
\hline 18 Jun & & 5 & & & & & & & & & & 1 & 5 & 1 & & & 1 & \\
\hline $2 \mathrm{Jul}$ & & 3 & & & & & & & & & 1 & & 2 & & & & & \\
\hline $16 \mathrm{Jul}$ & & 1 & & & & & & & & & & & 1 & & & & & \\
\hline Sample size & 7 & 162 & 1 & 9 & 29 & 14 & 5 & 11 & 3 & 11 & 55 & 113 & 73 & 10 & 33 & 10 & 14 & 37 \\
\hline
\end{tabular}


prey. Under the ice of Hudson Bay in spring, firstfeeding (<9 mm long) polar cod prey on copepod eggs ( 0 to $13 \%$ of diet by number) and nauplii (67 to $95 \%$ of diet), primarily those of Oithona similis, Pseudocalanus spp. and Oncaea borealis (Fortier et al. 1995). In the Northeast Water (Greenland Sea) in spring, firstfeeding larvae $(<8 \mathrm{~mm}$ long) prey on eggs of large calanoid copepods $(16 \%)$ such as Calanus hyperboreus, C. glacialis and Metridia longa, and on nauplii $(80 \%)$, primarily those of Oithona similis, Pseudocalanus spp. and Microcalanus pusillus (Michaud et al. 1996). The pelagic C. hyperboreus releases eggs starting in mid-January in the Canadian High Arctic and from November to April in the Greenland Sea (Conover \& Siferd 1993, Hirche \& Niehoff 1996). However, the neritic C. glacialis and Pseudocalanus spp. spawn in response to microalgal production and their eggs and nauplii occur in late spring (e.g. Kosobokova \& Hirche 2001, Ringuette et al. 2002). In the Beaufort Sea, Metridia longa releases its eggs starting in midMarch (G. Darnis, Université Laval, pers. comm.). In contrast, indications are that reproduction of the small omnivorous Microcalanus sp., Oithona similis and Oncaea borealis is continuous throughout the year in polar seas (Ringuette et al. 2002 and references therein). Therefore, the food available to polar cod larvae hatched in the Laptev Sea in winter and early spring likely consisted of the naupliar stages of these small omnivorous copepods and the eggs of Calanus hyperboreus and Metridia longa.

\section{Polynyas and the pre-winter size of young polar cod}

Matching the first feeding of larvae with the brief maximum production of copepod eggs and nauplii in early summer has been identified as a dominant force constraining the reproduction strategy of polar cod (e.g. Graham \& Hop 1995, Fortier et al. 1995). Another major determinant of early survival in marine fish is predation. In August/September, the diet of Arctic seabirds such as the abundant dovekie Alle alle shifts to polar cod pelagic juveniles (e.g. Karnovsky \& Hunt 2002). At the end of life in the plankton in September, polar cod fry descend to deeper water and begin to occur in the stomach contents of juvenile and adult polar cod (Baranenkova et al. 1966). The larger the young polar cod are at the end of the short Arctic summer, the less vulnerable they will be to avian predation in early fall and cannibalism over the winter. In the Northeast Water in 1993, a spring cohort (14 May to 15 June) of larvae was hatched under the ice at subzero temperatures and survived poorly (Fortier et al. 2006). A summer cohort (21 June to 21 July) was hatched at above-zero temperature and survived well.

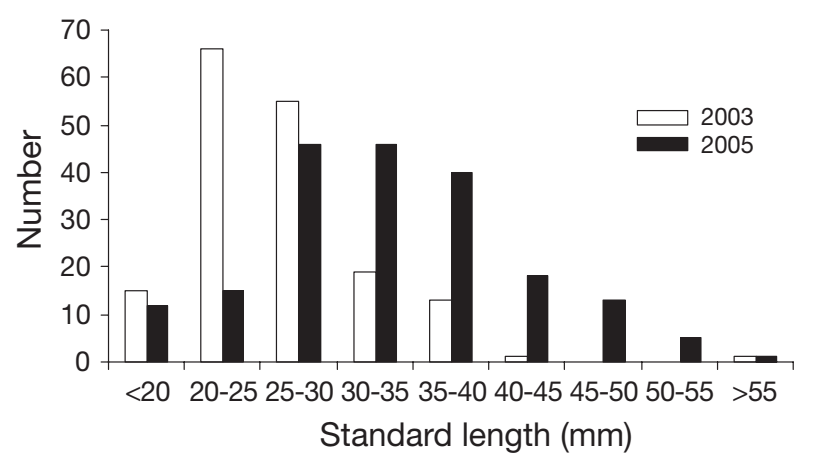

Fig. 10. Boreogadus saida. Length frequency distribution of polar cod collected in the Laptev Sea from September 1 to 11, $2003(n=170)$ contrasted with the back-calculated length frequency distribution for the same dates for fish sampled in 2005 ( $\mathrm{n}=427)$. Fish were collected on average $10 \mathrm{~d}$ later in 2005 (September 10 to 21) than in 2003. To remove this bias, the standard length at age $10 \mathrm{~d}$ before capture was backcalculated from the otolith for fish sampled in 2005

However, by early August the few surviving larvae of the spring cohort were on average $5.7 \mathrm{~mm}$ longer than summer larvae (18.6 versus $12.9 \mathrm{~mm})$, which suggests a trade-off between early survival and maximizing pre-winter size to avoid predation (Fortier et al. 2006).

In the Laptev Sea, all fish captured in September were hatched from January to early July, well before the ice break-up and the early summer production of copepod prey. Larvae hatched in early July were $<20 \mathrm{~mm}$ long by September, while hatching in January allowed some fish to attain pre-winter lengths $>55 \mathrm{~mm}$, providing early hatchers with a clear advantage in avoiding predators. Interannually, a consistently larger length at age in 2005 (on average by $3.98 \mathrm{~mm}$ ) relative to 2003 was associated with higher frequencies and opening extents of coastal polynyas. The end result was that, after correcting for the bias due to later sampling in 2005, the average pre-winter length of polar cod was on average $8.6 \mathrm{~mm}$ longer in $2005(34.8 \mathrm{~mm})$ than in $2003(26.2 \mathrm{~mm})$, reflecting both faster initial growth and the presence of older, earlierhatched fish in the 2005 population (Fig. 10). We propose that maximizing pre-winter size to reduce predation (rather than matching first feeding with maximum production of copepod eggs and nauplii) is the main force dictating winter/spring hatching in polar cod. In coastal seas influenced by large rivers, sub-lethal temperatures and the availability of light and prey in winter-spring polynyas allow polar cod to hatch early and achieve a large pre-winter size. In regions less influenced by freshwater (North Water, Northeast Water, Barents Sea) hatching is delayed until the warming of the surface layer at ice break-up and the vernal production of prey, at the cost of relatively small pre-winter size and, presumably, higher vulnerability to predation in fall and winter. 
Our results suggest that, at least in the short term, the survival of polar cod larvae in the Laptev Sea could be favored by more frequent winter and spring polynyas, leading to enhanced recruitment, and potentially larger populations. However, different stages in the life cycle of the species are closely adapted to (and strongly dependent on) sea ice (e.g. Lønne \& Gulliksen 1989, Gradinger \& Bluhm 2004). In the longer term, as sea ice becomes seasonal, polar cod is likely to be replaced by one or several circumpolar generalists such as the boreal capelin Mallotus villosus as the main forage fish of the Arctic Ocean.

Acknowledgements. We thank the captain and crew of the Russian icebreaker Kapitan Dranitsyn. Thanks to D. Dumont, A. Forest, R. Lanos, M. Ringuette, and P. Smith, for their help at sea, and to H. Cloutier for otolith validation. Special thanks to D. Barber and W. Chan of the Center for Earth Observation Science at the University of Manitoba for ice data. This study was funded in part by ArcticNet, a Network of Centres of Excellence of Canada, and the Natural Science and Engineering Council of Canada. Logistics in the Arctic were provided by the Nansen and Amundsen Basins Observational System (NABOS) at the International Arctic Research Center (University of Alaska in Fairbanks). C.B. received financial support from the Fonds québécois de recherche sur la nature et la technologie (FQRNT), the Northern Scientific Training Program (NSTP) of the Ministry of Indian and Northern Affairs Canada, and the ArcticNet training fund. This is a contribution to Québec-Océan at Université Laval, ArcticNet and the Canada Research Chair on the response of marine arctic ecosystems to climate warming. The insightful comments of 2 anonymous reviewers are gratefully acknowledged.

\section{LITERATURE CITED}

Baranenkova AS, Ponomarenko VP, Khokhlina NS (1966) The distribution, size and growth of the larvae and fry of Boreogadus saida (Lep.) in the Barents Sea. Can Fish Mar Serv Transl Ser 4025 (1977)

Bareiss J, Gorgen K (2005) Spatial and temporal variability of sea ice in the Laptev Sea: analyses and review of satellite passive-microwave data and model results, 1979 to 2002 . Global Planet Change 48:28-54

Campana SE, Jones CM (1992) Analysis of otolith microstructure data. Can Spec Publ Fish Aquat Sci 117:73-100

Cavalieri D, Parkinson C, Gloerson P, Zwally HJ (1996, updated 2006) Sea ice concentrations from Nimbus-7 SMMR and DMSP SSM/I passive microwave data, 2003 and 2005. National Snow and Ice Data Center, Boulder, CO. Digital media. (http://nsidc.org/data/nsidc-0051.html)

Conover RJ, Siferd TD (1993) Dark season survival strategies of coastal zone zooplankton in the Canadian Arctic. Arctic 46:303-311

Cushing DH (1969) The regularity of the spawning season of some fishes. ICES J Mar Sci 33:81-92

Deming J, Fortier L, Fukuchi M (2002) The international North Water polynya study (NOW): a brief overview. Deep-Sea Res II 49:4887-4892

Fortier L, Ponton D, Gilbert M (1995) The match/mismatch hypothesis and the feeding success of fish larvae in icecovered southeastern Hudson Bay. Mar Ecol Prog Ser 120: $11-27$

Fortier L, Gilbert M, Ponton D, Ingram RG, Robineau B, Legendre L (1996) Impact of freshwater on a subarctic coastal ecosystem under seasonal sea ice (southeastern Hudson Bay, Canada). III. Feeding success of marine fish larvae. J Mar Syst 7:251-265

Fortier L, Sirois P, Michaud J, Barber D (2006) Survival of Arctic cod larvae (Boreogadus saida) in relation to sea ice and temperature in the Northeast Water Polynya (Greenland Sea). Can J Fish Aquat Sci 63:1608-1616

Gradinger RR, Bluhm BA (2004) In-situ observations on the distribution and behavior of amphipods and Arctic cod (Boreogadus saida) under the sea ice of the High Arctic Canada Basin. Polar Biol 27:595-603

Graham M, Hop H (1995) Aspects of reproduction and larval biology of Arctic cod (Boreogadus saida). Arctic 48: 130-135

Hirche HJ, Niehoff B (1996) Reproduction of the copepod Calanus hyperboreus in the Greenland Sea and laboratory observations. Polar Biol 16:601-612

Karnovsky NJ, Hunt GL Jr (2002) Estimation of carbon flux to dovekies (Alle alle) in the North Water. Deep-Sea Res II 49:5117-5130

Kosobokova KN, Hirche HJ (2001) Reproduction of Calanus glacialis in the Laptev Sea, Arctic Ocean. Polar Biol 24: $33-43$

Lønne OJ, Gulliksen B (1989) Size, age and diet of polar cod, Boreogadus saida (Lepechin 1773), in ice covered waters. Polar Biol 9:187-191

Michaud J, Fortier L, Rowe P, Ramseier R (1996) Feeding success and survivorship of Arctic cod larvae, Boreogadus saida, in the Northeast Water polynya (Greenland Sea). Fish Oceanogr 5:120-135

Nghiem SV, Chao Y, Neumann G, Li P, Perovich DK, Street T, Clemente-Colon P (2006) Depletion of perennial sea ice in the East Arctic Ocean. Geophys Res Lett 33:L17501

Ponomarenko VP (2000) Eggs, larvae, and juveniles of polar cod Boreogadus saida in the Barents, Kara, and White Seas. J Ichthyol 40:165-173

Ponton D, Fortier L (1992) Vertical distribution and foraging of marine fish larvae under the ice cover of southeastern Hudson Bay. Mar Ecol Prog Ser 81:215-227

Rass TS (1968) Spawning and development of polar cod. Rapp P-V Reun Cons Perm Int Explor Mer 158:135-137

Ringuette M, Fortier L, Fortier M, Runge J and others (2002) Accelerated population development of Arctic calanoid copepods in the North Water polynya. Deep-Sea Res II 49:5081-5099

Stroeve J, Holland M, Meier W, Scambos T, Serreze M (2007) Arctic sea ice decline: faster than forecast. Geophys Res Lett 34:L09501

Timokhov L (1994) Regional characteristics of the Laptev and the East Siberian Seas: climate, topography, ice phases, thermohaline regime and circulation. Ber Polarforsch 144: $15-31$

Valerio PF, Goddard SV, Ming HK, Fletcher GL (1992) Survival of northern Atlantic cod (Gadus morhua) eggs and larvae when exposed to ice and low temperature. Can J Fish Aquat Sci 49:2588-2595

Zakharov VF (1997) Sea ice in the climate system. World Climate Research Programme/Arctic Climate System Study, WMO/TD No. 782. World Meteorological Organization, Geneva 